ICTD Working Paper 121

Taxing Agricultural Income in the Global South: Revisiting Uganda's National Debate

Graeme Stewart-Wilson and Ronald Waiswa

April 2021 
Taxing Agricultural Income in the Global South: Revisiting Uganda's National Debate Graeme Stewart-Wilson and Ronald Waiswa

ICTD Working Paper 121

First published by the Institute of Development Studies in April 2021

(C) Institute of Development Studies 2021

ISBN: [978-1-78118-798-2]

DOI: [10.19088/ICTD.2021.008]

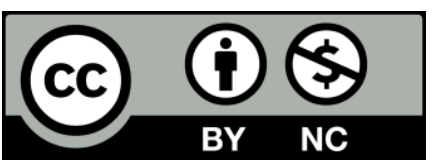

This is an Open Access paper distributed under the terms of the Creative Commons Attribution Non Commercial 4.0 International license, which permits downloading and sharing provided the original authors and source are credited - but the work is not used for commercial purposes. http://creativecommons.org/licenses/by-nc/4.0/legalcode

Available from:

The International Centre for Tax and Development at the Institute of Development Studies, Brighton BN1 9RE, UK

Tel: +44 (0) 1273606261

Email:info@ictd.ac

Web: www.ictd.ac/publication

Twitter: @ICTDTax

Facebook: www.facebook.com/ICTDtax

IDS is a charitable company limited by guarantee and registered in England

Charity Registration Number 306371

Charitable Company Number 877338 


\title{
Taxing Agricultural Income in the Global South: Revisiting Uganda's National Debate
}

\author{
Graeme Stewart-Wilson and Ronald Waiswa
}

\section{Summary}

The issue of agricultural taxation has almost completely disappeared from the scholarly and policy agendas in recent decades. And yet, agriculture is taxed very lightly despite contributing substantially to GDP across many Global South countries today. In some cases, light-touch taxation may be necessary to encourage investment in the sector and to protect small and subsistence farmers. However, anecdotal evidence from countries like Uganda suggests that there are a substantial number of high-income earners engaged in agricultural activities that are sheltered almost completely from any form of taxation. More effectively taxing these high-income earners could provide much-needed resources to finance public service provision in lower-income countries. The time is ripe, this paper argues, to revitalise discussions about how best to tax the agriculture sector.

In Uganda, taxation of the agriculture sector has historically been the subject of intense political contestation. In 2018, Parliament adopted a revised 1 per cent withholding tax (WHT) on the supply of agricultural products. Although the revised WHT raised significant revenue in its first year it faced a strong political backlash, and was abandoned in 2019. Currently, the agriculture sector accounts for roughly 22 per cent of GDP in Uganda, but contributes less than 1 per cent of tax revenue. While many participants in the agriculture sector are smallholder or subsistence farmers, internal URA investigations show that there are also highly profitable suppliers of agricultural products that pay little or no taxes.

There are four potential strategies that Uganda could pursue to collect taxes more fairly from the agriculture sector in the short and medium term. First, Parliament could reinstate some level of WHT on the sector. While politically controversial, WHTs are one of the only ways to successfully collect income taxes from the sector. Second, URA could upgrade the existing WHT system to require the clear identification of agricultural suppliers. Suppliers could then be tracked more effectively to ensure they are complying with existing income tax obligations. Third, the URA could put its internal data to better use by specifically targeting the largest agricultural suppliers - who are also likely to be the most profitable - to make sure that they are registered with the URA and complying with their existing tax obligations. And fourth, URA could increase enforcement on non-compliant agricultural suppliers, beginning with the largest firms.

This paper summarises early debates on taxation of the agriculture sector, before turning to the contemporary context of Uganda. The paper includes a discussion of some URA investigations that have begun the process of identifying high income-earners in the sector. The paper next outlines some potential strategies Uganda could pursue to tax the agriculture sector more fairly. The paper concludes with a discussion about overcoming the strongest political resistance to agricultural taxation, and a series of recommendations for the way forward.

Keywords: agriculture; taxation; income tax; withholding tax; Uganda; sub-Saharan Africa.

Graeme Stewart-Wilson is a PhD student in political science at the University of Toronto and a researcher with the ICTD. His research focuses on tax reform in sub-Saharan Africa. 
Ronald Waiswa is a Research and Policy Analysis Supervisor at the Uganda Revenue Authority. He has collaborated with the ICTD on a number of research projects in Uganda on issues including taxing wealthy individuals and public sector agencies. 


\section{Contents}

Summary 3

Acknowledgements $\quad 6$

Acronyms $\quad 6$

$\begin{array}{ll}\text { Introduction } & 7\end{array}$

$1 \quad$ History of agricultural taxation in the Global South 9

$2 \quad$ Agricultural taxation in Uganda: theory and practice 13

$\begin{array}{ll}2.1 & \text { URA compliance investigation: sugarcane outgrowers }\end{array}$

$\begin{array}{ll}2.2 & \text { URA compliance investigation: fish suppliers } \\ \end{array}$

$3 \quad$ Use of withholding taxes in Uganda 16

$4 \quad$ Strategies to collect revenue from the agriculture sector more fairly 17

4.1 Reinstate the WHT on agricultural supplies 18

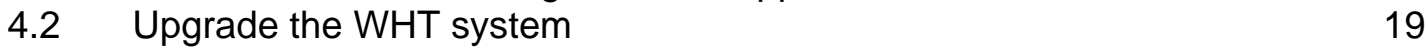

4.3 Target highly profitable agricultural suppliers for registration 20

4.4 Increase enforcement on non-compliant taxpayers 20

$5 \quad$ Making agricultural taxation a political reality 21

6 Recommendations for the way forward 22

$\begin{array}{lr}\text { References } & 24\end{array}$

Tables

Table 1

Table 2

Table 3

Table 4

Table 5

Table 6

Taxonomy of methods to tax the agriculture sector in the Global South

10

Percentage contribution to total revenue by sector 13

Taxpayer registration by agricultural sub-sector $\quad 14$

Tax compliance in the agriculture sector by tax type 15

Withholding taxes collected in Uganda by financial year 17

Withholding taxes collected in Uganda by transaction type

(USh bn and \%)

Figures

Figure 1

Revenue contribution by tax head in the agriculture sector (USh billion) 


\section{Acknowledgements}

The authors would like to thank Rhiannon McCluskey for encouraging us to turn a short blog post into a working paper. The authors would also like to thank the anonymous ICTD reviewers for their thorough comments, and URA colleagues in the Tax Investigations Department, specifically Alex Nuwagira and lan Mwesigye, for their useful input on earlier drafts of this paper.

\section{Acronyms}

$\begin{array}{ll}\text { CSO } & \text { Civil society organisation } \\ \text { GST } & \text { Goods and services tax } \\ \text { HNWI } & \text { High net worth individual } \\ \text { MP } & \text { Member of parliament } \\ \text { NAADS } & \text { National Agricultural Advisory Services } \\ \text { OWC } & \text { Operation Wealth Creation } \\ \text { PAYE } & \text { Pay As You Earn } \\ \text { TIN } & \text { Taxpayer identification number } \\ \text { TJNU } & \text { Tax Justice Network Uganda } \\ \text { UBOS } & \text { Uganda Bureau of Statistics } \\ \text { URA } & \text { Uganda Revenue Authority } \\ \text { VAT } & \text { Value added tax } \\ \text { WHT } & \text { Withholding tax }\end{array}$




\section{Introduction}

Agriculture is lightly taxed across much of the developing world today, although it contributes substantially to GDP (Bird 1974; Khan 2001; OECD 2019; Rajaraman 2005). Low effective tax rates in the agriculture sector are often a consequence of intentional policy decisions. Many developing economies remain defined, in large part, by an extensive reliance on subsistence agriculture in rural areas (Goedde et al. 2019). Governments may thus exempt large parts of the agriculture sector from taxation as a means of protecting small and poor farmers. Governments may also seek to protect the sector from taxation to encourage investment, as increased agricultural productivity features prominently in many national-level development strategies. The agriculture-led structural transformation advocated by the African Union relies on increased investment in the sector to modernise smallholder agriculture and promote the growth of agribusiness (Timmer et al. 2012). Tax policy may be used to incentivise this structural transformation. The agriculture sector may also be taxed lightly in many countries because of a well-organised agricultural lobby that resists any efforts to increase levels of taxation (Ahmed and Mohammed 2010).

Low levels of agricultural taxation today are largely a result of the way in which economic theories about the role of agriculture in development have shifted over time. In the postindependence era, many African governments taxed the agriculture sector through pricing policies and export taxes (Sarris 1994). Beyond raising revenue, the purpose of these policies was to transfer a substantial portion of agricultural surplus to industry in urban areas to stimulate broader economic modernisation (Khan 2001). These policies were strongly attacked in the early 1980 s by many economists and multilateral lending institutions, such as the World Bank and IMF, on the grounds that they are highly distortionary (Sarris 1994). Stabilisation and structural adjustment lending during the period was then made contingent on, among other things, 'getting the prices right', which implied a substantial reduction in the implicit taxation of agriculture (Sarris 1994).

Direct taxation mechanisms, such as income taxes, were proposed to fill the revenue gap, as income tax is widely understood not to induce income transfers between sectors, and to have a smaller distortionary effect on resource allocation decisions (Khan 2001). Income taxes, however, encounter three major challenges in developing countries: (1) they face strong and vocal opposition; (2) they are hard to asses; and (3) they are expensive to enforce and administer (Khan 2001). In the agriculture sector earned income is hard to measure, as much production occurs on a small scale, a substantial part of the output is consumed rather than marketed, and no records are kept for the cost of inputs and quantity of outputs (Khan 2001). As a result of these challenges, income taxes have not filled the gap left by the reduction of price controls and export taxes. Although agriculture accounts for a substantial amount of economic activity in many developing countries, it remains very lightly taxed.

In Uganda, the agriculture sector accounts for roughly 22 per cent of GDP, and about 64 per cent of the working-age population is employed in the sector (UBOS 2019). Despite this large contribution to economic activity in the country, the sector contributes less than 1 per cent of total tax revenue collected by the Uganda Revenue Authority (URA) (UBOS 2019). The wholesale and retail sector, by contrast, contributes 29 per cent of tax revenue, while accounting for 9 per cent of GDP; the manufacturing sector contributes 22 per cent of revenue with 16 per cent of GDP (UBOS 2019).

Agriculture is taxed very lightly compared to other important sectors. Low levels of tax collection from the sector are in part the result of agricultural inputs being protected from value added tax (VAT). To encourage investment, most agricultural inputs are either exempt or zero-rated for VAT in Uganda (URA 2014). The supply of machinery and tools suitable for agriculture, and the supply of livestock, are exempt from VAT. The supply of seeds, 
fertilisers, pesticides and hoes are zero-rated (Okuja 2018). As a result, VAT collection from the agriculture sector is marginal. Although agricultural income above the base threshold of USh2.8 million (US\$760) is technically liable for income tax, there is a widespread perception in Uganda that income from agriculture is not taxable. As a result, income tax compliance in the sector is very low.

Uganda has long relied on a withholding tax (WHT) regime to counter the challenges of collecting income tax. Withholding taxes are typically employed as a way of collecting income tax, usually through a pay-as-you-earn (PAYE) mechanism. Employers are designated as withholding agents, and directly withhold a portion of employee salaries from their pay cheques for reversion to revenue authorities. The amount withheld is considered a credit against the income tax owed by an employee - if too much money is withheld, the employee receives a tax refund; if not enough is withheld, the employee receives an additional tax bill. Such PAYE withholding schemes are used widely in both developed and developing countries to collect income tax (Martin 2018). Withholding taxes are used much more liberally in Uganda because of the challenges inherent in collecting income tax. A flat 6 per cent withholding rate is applied on a wide range of transactions, including goods and service purchases by government agencies and large private companies, management and professional fees, and imports (URA 2019).

The supply of agricultural products was subject to the standard 6 per cent WHT rate from 1997. However, this rate was perceived as excessive by agricultural producers, and was not enforced by the URA. In 2018, Uganda lowered the WHT rate on the supply of agricultural products to 1 per cent, and the URA began to aggressively enforce the new lower rate. In its first year the 1 per cent withholding rate on agricultural supplies raised USh33 billion, almost double the total income tax collected from the sector in the same year. However, as the URA had not previously enforced the standard 6 per cent rate in the sector, the new 1 per cent rate was widely interpreted as a new tax. Strong and organised resistance to the new withholding rate emerged from the agricultural lobby, and Parliament subsequently overturned the provision and exempted the supply of agricultural products from the overall WHT regime.

Despite the light taxation of the sector, a number of URA investigations have found some unregistered agricultural suppliers making sales in excess of USh1 billion annually. These agricultural producers should, in theory, be subject to income taxation. Prior research has also identified agriculture as a key wealth-banking mechanism used by high net worth individuals (HNWIs) in Uganda (Kangave et al. 2016). Identifying and registering these potential large taxpayers, however, poses a persistent challenge for the URA. Little data is available on transactions, payments are often made in cash and not routed through the banks, and agricultural suppliers do not use standard bookkeeping practices to track expenses and sales throughout the year (Rajaraman 2005).

Given the persistent light taxation of agriculture, coupled with emerging evidence of some high-income earners in the sector, this paper argues that it is time to revisit the question of agricultural taxation in Uganda. The recent experience of the coronavirus pandemic has highlighted some weaknesses in Uganda's tax system that the relatively stable agriculture sector could help to mitigate (Stewart-Wilson and Waiswa 2020). This paper first reviews the literature on agricultural taxation in the Global South. While various strategies to collect revenue from the sector were proposed and discussed throughout the 1970s and 1980s, agricultural taxation has disappeared almost entirely from the scholarly and policy agenda on domestic revenue mobilisation. Second, the paper unpacks the context of agricultural taxation in Uganda, including the distinction between how agriculture is taxed on paper, and how it is taxed in practice. This section also outlines the results of two tax compliance 
investigations conducted by the URA on the agriculture sector that reveal the presence of high, untaxed income. Third, the paper discusses some possible strategies that could be used to tax the sector more fairly, and their potential impact. Fourth, the paper outlines the political challenges to taxing the agriculture sector more appropriately in Uganda, and identifies some possible strategies to navigate these challenges. Overall, this paper argues that it is time for Uganda to revisit the national conversation about taxing the agriculture sector, in a way that is equitable and increases the government's ability to respond to crises like the coronavirus pandemic.

\section{History of agricultural taxation in the Global South}

Historically, the main objectives of agricultural taxation have been to (1) generate government revenue, and (2) transfer a substantial proportion of the resources from agriculture to the rest of the economy (Khan 2001). These objectives were rooted in the development strategies adopted by many post-independence countries. The overall goal was rapid capital accumulation for industrial growth through the deliberate extraction and redistribution of surplus value from the agriculture sector (Khan 2001). A large part of the tax burden on agricultural producers was historically due to implicit taxes levied through measures like overvalued exchange rates, non-tariff barriers such as export quotas, import tariffs on substitute goods, and price-setting through national procurement programmes (e.g. monopoly agricultural marketing boards) (Bates 1981; Khan 2001). Such implicit taxes on agriculture were often preferred because of their relative administrative simplicity (Bird 1974).

Arguments about the adverse economic consequences of such implicit taxes, however, are now well-known:

1. They did not contribute to a more rapid overall growth of real gross national product, or of industry (Schiff and Valdés 1992).

2. Although many countries gained revenue from these policies over the short-term, revenue tended to decrease sharply over the long-term (Valdés 1996).

3. These implicit taxes tended to have large disincentive effects on agricultural investment (Bird 1974).

4. Income redistribution overall was quite small, with many countries seeing a reduction in the income of poor urban households, contrary to the goal of these policies (Krueger 1991).

As a result of these arguments, structural adjustment programmes promoted by the multilateral lending institutions included the removal of these implicit taxes as part of their loan conditionalities (Sarris 1994). The burden of indirect taxes on the agriculture sector has fallen dramatically in most developing countries over the past few decades - in part due to loan conditionalities, and in part due to the broader diversification of economic structures and exports (Khan 2001). 
Table 1 Taxonomy of methods to tax the agriculture sector in the Global South ${ }^{2}$

\begin{tabular}{|c|c|c|}
\hline \multirow{2}{*}{ Implicit taxes } & \multicolumn{2}{|l|}{ Explicit taxes } \\
\hline & Direct taxes & Indirect taxes \\
\hline $\begin{array}{l}\text { 1. Overvalued exchange rates } \\
\text { 2. Non-tariff barriers } \\
\text { 3. Import tariffs } \\
\text { 4. Procurement programmes } \\
\text { (monopoly marketing) }\end{array}$ & $\begin{array}{l}\text { 1. On actual income (by category of } \\
\text { income, or on global income) } \\
\text { 2. On presumed income (from land) } \\
\text { - Withholding based on a \% of sales } \\
\text { - } \quad \text { Based on land area } \\
\text { On rental income (annual rental } \\
\text { value or capital value) } \\
\text { - Value of gross or net income } \\
\text { 3. Personal (or poll) tax } \\
\text { - On individual or household } \\
\text { - On livestock } \\
\text { 4. Wealth or property tax } \\
\text { - Based on area with adjustments } \\
\text { - } \quad \text { Based on capital (market) value } \\
\text { - } \quad \text { Based on land improvements }\end{array}$ & $\begin{array}{l}\text { 1. Tax on domestic trade (GST/VAT } \\
\text { and turnover tax) } \\
\text { 2. Tax on foreign trade (import duty } \\
\text { and export tax) } \\
\text { 3. Excise on specific marketed } \\
\text { products } \\
\text { 4. Cess on specific market products } \\
\text { 5. Stamp duty }\end{array}$ \\
\hline
\end{tabular}

Explicit taxes are the alternative to such implicit taxes, and have also been deployed by many Global South countries over the past decades. Explicit taxes take a number of different forms, and their distribution varies greatly country by country. In general, they can be separated into direct and indirect variants, and encompass such measures as: (1) direct taxes on income - actual or presumed, persons (head or poll taxes), and wealth or property (especially agricultural land) taxes, and (2) indirect taxes such as sales taxes (e.g. GST, VAT), and export taxes (Khan 2001). Indirect taxes also include mechanisms like excise (a consumption tax applied to a specific good), cess (an earmarked levy on specific marketed crops, the proceeds of which are typically reserved to improve the production and marketing of those crops), and stamp duties (a flat fee typically applied to legal forms, such as, agricultural land transfer documents). In sum, agricultural taxation in Global South countries is often defined by a curious mixture of various taxes and charges, many of which were levied for different emergencies in the past and never removed (Ahmad and Stern 1989).

Of all the explicit tax options available to Global South governments, export taxes have produced the most revenue (Bird 1974). A major argument in favour of export taxes is that they can generate substantial government revenue, and are relatively easy and inexpensive to administer (Khan 2001). In Uganda's case, export duty - derived mainly from coffee exports - contributed up to 50 per cent of total government revenue during the 1980s (Devarajan et al. 1996). Since then, however, there has been a growing recognition that export taxes produce distortionary economic incentives, as they can be shifted onto producers in the form of lower prices, which in turn leads to less investment and lower growth rates in the agriculture sector (Bates 1981; Devarajan et al. 1996; Khan 2001). Export taxes are also liable to produce unstable and unpredictable revenue flows, as they fluctuate with global commodity prices (Bird 1974). As a result, the burden of export taxes on agricultural producers in many developing countries has fallen over the past two decades (Khan 2001).

In other sectors of the economy, VAT and similar consumption taxes have been deployed to fill the gap left by export taxes. In the case of agriculture, however, most outputs and inputs are either zero-rated or exempt from VAT to encourage growth and investment in the sector.

Table adapted from (Khan 2001). 
VAT contributes very little revenue from the agriculture sector in most Global South countries.

The reluctance to apply indirect consumption taxes like VAT to agriculture has a lot to do with the way that the role of agriculture has shifted in theories of development. The objective of early tax policies targeting the sector was, at least in part, to redistribute resources away from agriculture and into the urban-based industrial sector of the economy (Sarris 1994). More recently, agriculture has come to occupy a central role in development strategies, with governments seeking to increase productivity through investments in value addition and mechanisation (Timmer et al. 2012). As a result of this, governments are reluctant to apply consumption taxes to the agriculture sector. There is also a growing acknowledgement of the political challenges of raising revenue from agriculture. Agriculture is frequently the main source of foreign exchange, it often employs the majority of people, and governments in democratic countries tend to be accountable mainly to rural populations (Ahmed and Mohammed 2010). Contemporary governments thus face few incentives to increase taxation of the agriculture sector.

Global South countries thus have to use direct taxes to fill revenue gaps left by the reduction of implicit and indirect taxes. Agricultural land taxes were discussed as a viable, less distortionary direct alternative to implicit and indirect taxes for some time (Bird 1974; Skinner 1993). Economists tend to support the application of land taxes, because land is easily observable and is in fixed supply (Skinner 1993). Land tax is also theorised to cause minimal economic distortion of output prices - farmers have an incentive to produce at high levels because they receive the full price of their crops (Hoff 1991). Despite these theoretical benefits, agricultural land tax has rarely been used as a serious revenue source in Global South countries (Skinner 1993).

The lack of effective agricultural land taxes in the Global South has typically been attributed to its administrative difficulties, and in particular the challenge of land valuation (Skinner 1993). The intrinsic value of land cannot be known, and deploying a large cohort of trained officials to estimate land value is prohibitively expensive (Skinner 1993). To circumvent this problem, some countries have implemented presumptive systems of land taxation based on land area. Presumptive area-based systems of land taxation, however, have the potential to be highly regressive if wealthier landowners tend to own more fertile, and thus more profitable, land (Skinner 1993). One option to make the presumptive land tax more equitable is to adjust area-based value estimates with some measure of soil quality. However, in addition to increasing the administrative complexity of land taxation, such systems still encounter the problem of identifying legal landowners. Due to unclear land tenure across much of the developing world, linking cadastral records to ownership has often proved impossible, even when land values could be systematically assessed (Bird 1974; Skinner 1993). Due to these challenges, efforts to tax agricultural land value have largely been abandoned across much of the Global South.

The main remaining mechanism to tax the agriculture sector effectively is income tax. Income taxes, however, face major administrative challenges in identifying taxpayers and determining taxable income (Bird 1974). Earned income in the agriculture sector is hard to measure for five main reasons (Khan 2001):

1. A large proportion of agriculture is conducted on a small scale.

2. A substantial proportion of agricultural production is consumed and not marketed.

3. Records are rarely kept for the cost of inputs, the quantity of outputs, and the amount of marketed output. 
4. Many Global South countries have multiple overlapping land tenure systems, making the appropriate distribution of input costs and outputs between farmers extremely complicated.

5. The cost to revenue agencies of verifying self-reported income from the agriculture sector is very high. Additionally, in many contexts, tax collection and enforcement responsibilities are divided between different levels of government, introducing a host of coordination and information-sharing problems (de Jantscher and Bird 1992).

As a result of these challenges, few Global South countries successfully enforce income tax obligations in the agriculture sector.

One potential way to enforce income tax obligations on agricultural income, at least in the short term, is through the use of withholding taxes. As discussed above, Uganda has had some success with the implementation of a withholding rate on the sector. In just one year, the 1 per cent withholding rate raised almost double the total income tax raised from the sector. Under the withholding system, certain large purchasers of agricultural supplies are designated as 'withholding agents', with a legal responsibility to remit a percentage of the total sale value to the URA. In theory, the withheld amounts are credited to the income tax owed by those supplying agricultural products to the large purchasers. In practice, however, this rarely happens, as so few agricultural suppliers actually file income taxes. Withholding tax thus provides a useful short-term measure to collect income taxes from suppliers in the sector, without the need to engage in resource-intensive registration drives and enforcement measures.

The main challenges to the use of WHTs in the agriculture sector seem to be political. Most members of parliament (MPs) are accountable to rural constituencies, and interviews in Uganda suggest that many MPs and top government officials are themselves large agricultural land owners, with investments in cattle ranches, commercial farms and forestry production. Parliament repealed the new withholding tax rate in Uganda in 2019, and no withholding tax is currently collected from the sector. Although the URA proposed a reintroduction of WHT on agricultural products in 2020, Parliament again rejected the proposal.

As a result of these developments, agricultural activity in Uganda continues to constitute a large portion of GDP, but contributes very little to tax revenue - and the situation is similar in many other Global South countries. From one perspective, light taxation of the agriculture sector might be desirable, as widespread subsistence farming should not be taxed. In the current policy environment, the main goal of limiting taxes on agriculture is usually to protect the sector until it is able to graduate to the point at which it should be subject to normal personal income and corporate income tax regimes. There is increasing anecdotal evidence from some developing countries, however, that there are highly profitable commercial suppliers in the agriculture sector that have in theory already graduated to this level, and yet continue to pay little or no taxes. It is important to now revisit the question of agricultural taxation in the Global South.

In parallel to these policy developments, academic interest in agricultural taxation has almost entirely vanished from the literature. A Google Scholar search for 'agricultural taxation in subSaharan Africa' yields, on the first page, only five relevant resources, all but one published before 2000. Scholars such as Richard Bird, Jonathan Skinner and David Newbery wrote extensively on the prospects for agricultural taxation in Africa between the 1970s and 1990s. Much of their work was published by multilateral lending institutions, such as the World Bank (Bird 1974; Newbery 1987; Skinner 1991, 1993). Since that time, however, there has been almost no substantial research on the question of agricultural taxation in sub-Saharan Africa. We hope that this paper can play a small role in rekindling interest in the subject. 


\section{Agricultural taxation in Uganda: theory and practice}

In theory, agricultural income in Uganda is subject to all the same tax instruments as other sectors of the economy. Income derived from agriculture above the base threshold of USh2.8 million should be taxed as any other income. In practice, however, traditional income taxation of the sector is extremely limited, and the URA faces a major challenge in enforcing compliance. Additionally, agricultural inputs such as machinery and livestock are exempted from VAT, while seeds, fertilisers and pesticides are zero-rated - the sector is effectively protected from the payment of consumption taxes on inputs. The practice of agricultural taxation in Uganda is thus significantly more limited than its theoretical potential.

According to the Uganda Bureau of Statistics (UBOS), in 2018/19 the agriculture sector accounted for 22 per cent of GDP, and 64 per cent of the working-age population was employed in agriculture (UBOS 2019). Despite this large contribution to the productive output of the country, in 2018/19 the agriculture sector contributed only 1 per cent to total tax revenue collected by the URA - this has stayed roughly the same since $2013 / 14$. In comparison, in 2018/19 the wholesale and retail sector contributed 29 per cent to tax revenue (with 8.7 per cent of GDP), and the manufacturing sector contributed 22 per cent (with 15.5 per cent of GDP) (UBOS 2019). The agriculture sector in Uganda is thus taxed very lightly relative to other important sectors of the economy.

Table 2 Percentage contribution to total revenue by sector

\begin{tabular}{|l|l|l|l|l|l|l|l|}
\hline Sector & FY2012/13 & FY2013/14 & FY2014/15 & FY2015/16 & FY2016/17 & FY2017/18 & FY2018/19 \\
\hline $\begin{array}{l}\text { Wholesale and retail } \\
\text { trade }\end{array}$ & 26.1 & 24.6 & 27.5 & 28.3 & 30.1 & 30.4 & 29.2 \\
\hline Manufacturing & 25.2 & 21.1 & 23.8 & 24.6 & 22.7 & 22.9 & 21.8 \\
\hline $\begin{array}{l}\text { Agriculture, forestry and } \\
\text { fishing }\end{array}$ & 0.6 & 0.8 & 1 & 0.9 & 0.9 & 0.9 & 1 \\
\hline
\end{tabular}

Low collection from some agricultural activities may be justified as a large number of farmers in Uganda operate at, or just above, subsistence level. By some estimates, over 40 per cent of Uganda's working-age population is engaged in subsistence agriculture (i.e. primarily for household consumption) (UBOS 2019). However, internal URA data also highlights a number of firms and individuals that make large sales of agricultural products, and appear to be highly profitable. In many cases, these suppliers benefit from large contracts to supply government agencies and other entities, although they are not registered with the URA.

In the context of this paper, those engaged in the sale of agricultural products, whether they are producers themselves or simply mid-level traders, are referred to in the aggregate as agricultural suppliers. Agricultural suppliers making large sales, and presumably earning high incomes, are nevertheless (1) protected by current tax legislation, and (2) largely not compliant with their existing tax obligations. These large suppliers are protected by legislation that exempts the sector from WHT, as well as by the exempt or zero-rated VAT status of agricultural inputs. They are largely non-compliant with existing obligations because of the challenges associated with enforcing income tax rules in the agriculture sector.

Additionally, taxation of the agriculture sector is seen as a relatively minor concern by the general public. Many Ugandans do not even know that agriculture-based income is taxable. As a result, compliance with existing legislation is generally low.

Despite these challenges, Uganda has managed to gradually increase revenue mobilisation from the agriculture sector. Between FY2015/16 and FY2019/20 revenue from the sector 
increased from USh46.5 billion to USh78.5 billion, an increase of roughly 90 per cent. This was driven primarily by expanded collection of PAYE from the sector, as the URA prioritised the registration of large firms with many employees. However, the growth in collection of PAYE targets employee salaries, and does little to reach the high incomes earned by some large suppliers in the sector.

Contributions from income tax and VAT to revenue have remained relatively static across this time period, due to the difficulty of collecting income tax from the sector, and exempt and zero-rated agricultural inputs, respectively. The large spike in total revenue collected from the sector in 2018/19, seen in Figure 1 below, was the result of the new 1 per cent withholding rate on the purchase of agricultural products, introduced in 2018. As the URA vigorously enforced this withholding rate across the country, it contributed a total of USh33 billion in FY2018/2019, almost twice the total income tax collected from the sector in the same year. With the repeal of the 1 per cent WHT in 2019, total revenue collected from the sector fell from USh108 billion to USh78.5 billion. The steadily increasing contribution of PAYE over time adds credence to the claim that withholding mechanisms are the only way to reliably increase tax collection from the agriculture sector over the short term in Uganda.

\section{Figure 1 Revenue contribution by tax head in the agriculture sector (USh billion)}

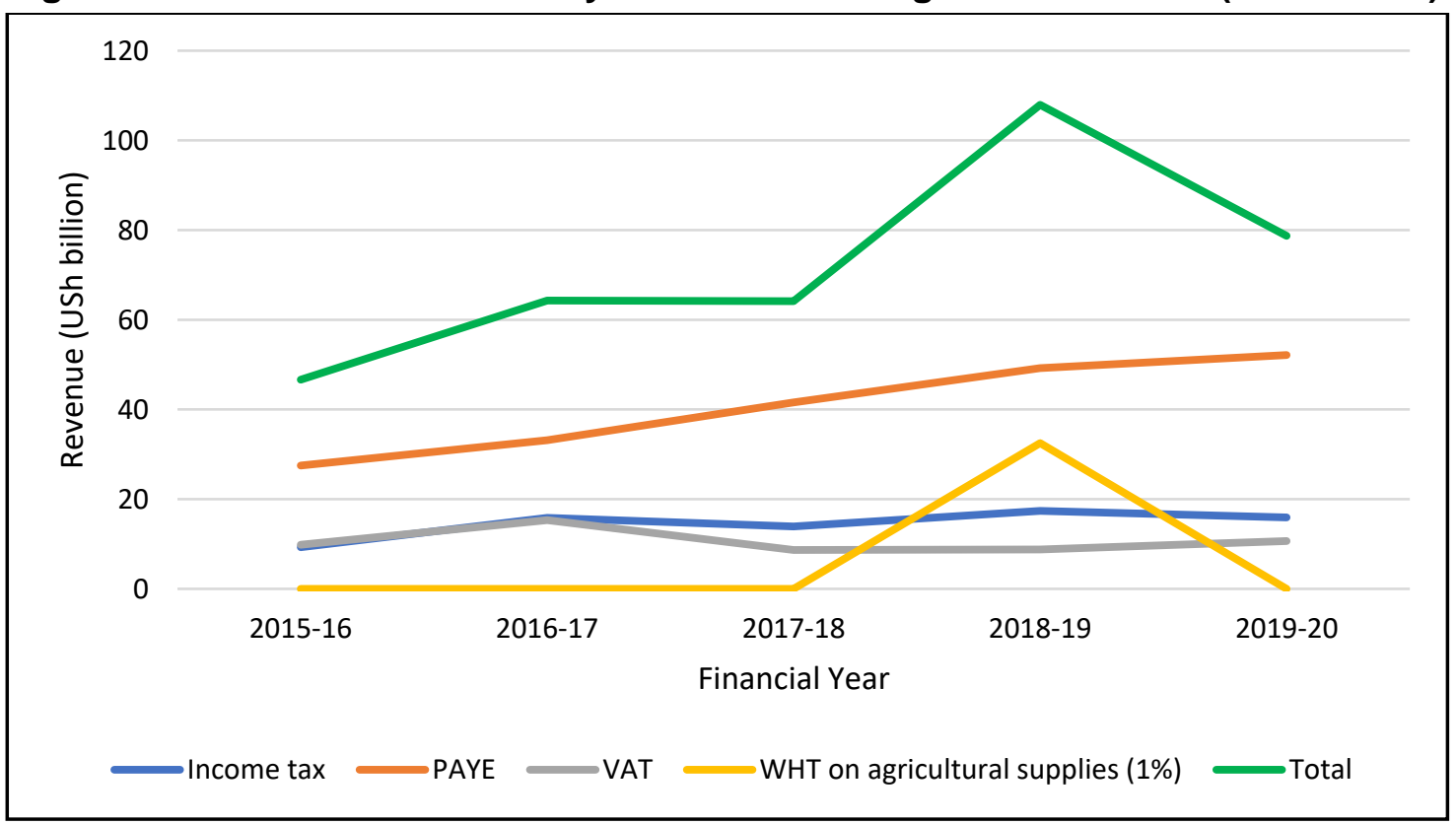

Despite an aggressive revenue drive over the past decade - and in particular targeting firms with many employees - the agriculture sector currently accounts for only 5.3 per cent of all registered taxpayers in Uganda (Mayega et al. 2019). At the end of March 2020, there were just over 84,000 registered taxpayers operating in the agriculture sector -81 per cent engaged in crop and animal production, 1.4 per cent in forestry, and 17.5 per cent in fishing and aquaculture.

Table 3 Taxpayer registration by agricultural sub-sector

\begin{tabular}{lrr}
\hline Sub-sector & No. of registered taxpayers & $\%$ share \\
\hline Crop and animal production & 68,632 & 81.1 \\
\hline Fishing and aquaculture & 14,811 & 17.5 \\
\hline Forestry and logging & 1,169 & 1.4 \\
\hline Total & 84,612 & 100.0 \\
\hline
\end{tabular}


Increasing numbers of agricultural taxpayers have been added to the register over time. However, compared to the volume of individuals engaged in the sector, penetration is still very low. In 2018/19 the sector accounted for an estimated 64 per cent of all working-age individuals - about 15 million people (UBOS 2019). The 84,000 registered agricultural taxpayers are only about 0.6 per cent of all individuals working in the sector. While many of these people are small-scale or subsistence farmers, interviews with URA officials suggest that there are also a substantial number of unregistered potential taxpayers in the sector.

Among those taxpayers in the agriculture sector that are registered, few are compliant with existing tax laws and regulations. Only 8 per cent $(6,003)$ of registered taxpayers paid some income tax in FY2018/19, up from just 5 per cent that paid some income tax in FY2017/18. Similarly, of the 883 taxpayers registered for VAT in the sector, only 54 per cent paid any VAT in $2018 / 19$. While these numbers seem relatively low, from the available data it is not possible to tell what percentage of registered taxpayers should be liable for income tax or VAT payments. The PAYE withholding tax on employee salaries is the only tax for which the large majority of registered taxpayers remitted some tax in 2018/19.

Table 4 Tax compliance in the agriculture sector by tax type

\begin{tabular}{|l|r|r|r|r|r|}
\hline \multirow{2}{*}{ Tax type } & Registered as of March & \multicolumn{2}{|c|}{$\begin{array}{r}\text { No. of taxpayers that paid some } \\
\text { tax }\end{array}$} & \multicolumn{2}{|r|}{\begin{tabular}{r} 
Proportion that paid some tax \\
\cline { 3 - 6 }
\end{tabular}} \\
\cline { 3 - 6 } & $\mathbf{2 0 2 0}$ & $\mathbf{2 0 1 7 / 1 8}$ & $\mathbf{2 0 1 8 / 1 9}$ & $\mathbf{2 0 1 7 / 1 8}$ & $\mathbf{2 0 1 8 / 1 9}$ \\
\hline Income tax & 76,664 & 4,170 & 6,003 & $5 \%$ & $8 \%$ \\
\hline PAYE & 883 & 511 & 617 & $58 \%$ & $70 \%$ \\
\hline VAT & 245 & 123 & 133 & $50 \%$ & $54 \%$ \\
\hline
\end{tabular}

To address the seemingly low levels of tax compliance in the sector, the URA investigated two sub-groups: sugarcane outgrowers and fish suppliers. This provides some initial anecdotal evidence on the presence of unregistered high-income earners in the sector.

\subsection{URA compliance investigation: sugarcane outgrowers}

Outgrower schemes, also known as contract farming, are broadly defined as binding arrangements through which a firm ensures its supply of agricultural products from individual or groups of farmers. The outgrower model is widely used in the sugarcane industry in Uganda - sugarcane wholesalers and processors purchase much of their inputs from independent contract sugarcane producers. In 2017, URA carried out an investigation of sugarcane outgrowers in Uganda to estimate the extent of revenue loss through tax noncompliance by outgrowers. The results indicate a wide scope for non-compliance among sugarcane outgrowers, although specific levels are difficult to determine. As a broad summary of the key points, the investigation revealed:

- There are a large number of sugarcane outgrowers operating in Uganda. The URA identified that the three largest sugar producers had contractual outgrower arrangements with more than 15,000 individual sugarcane farmers.

- Some outgrowers individually supplied sugarcane worth more than USh1 billion in 2015/16, and should therefore be income tax payers.

- Sugarcane outgrowers present a large source of potential tax revenue. Large firms pay an estimated USh300 billion annually to sugarcane outgrowers. Applying the standard WHT rate of 6 per cent to these sales translates into potential annual revenue of approximately to USh18 billion. Even at the reduced rate of 1 per cent implemented in 2019, a WHT could have generated roughly USh3 billion from the sub-sector - 32 per cent of all income tax collected from the entire agriculture sector in 2015/16.

- It is difficult for the URA to determine specific compliance behaviour in the sector. Most outgrowers do not have Taxpayer Identification Numbers (TINs), and therefore it is not 
possible to trace the payments made to outgrowers by wholesalers and processing firms. Before 2017/2018, agricultural purchases were not ring-fenced in the tax declarations of wholesalers and processing firms. It was thus not possible to tell if WHT remitted to the URA from withholding agents came from agricultural sources, as all withholding taxes were aggregated together.

\subsection{URA compliance investigation: fish suppliers}

Similar to sugarcane outgrowers, fisheries in Uganda rely on sub-contracting relationships with individual fishermen or groups of fishermen to secure their supplies. In 2017, URA investigated the fish supply industry to determine revenue potential and current noncompliance patterns. The investigation revealed a total of 135 fish suppliers who delivered supplies valued at more than USh135 billion in 2015/16 to the four largest fish processors in the country.

The results of the investigation indicated high levels of tax non-compliance among both fish suppliers and fish processors. Specifically:

- Of the 135 identified fish suppliers, $98(72 \%)$ were not registered at all with the URA.

- 31 of the 37 fish suppliers that were registered with URA did not file an income tax return in 2015/2016.

- Information obtained in the field showed that the 31 suppliers who did not file an income tax return had made sales worth more than USh53 billion in 2015/16. With enforcement of the 1 per cent withholding rate, these sales would have translated into USh530 million in revenue remitted from the four large fish processors, roughly equivalent to 6 per cent of all income taxes collected from the entire agriculture sector in that year.

- The investigation also found that fish processors themselves were grossly underdeclaring their purchases from suppliers to the URA.

In sum, URA investigations of specific, highly profitable industries in the agriculture sector have identified widespread income tax non-compliance, and a substantial number of large potential taxpayers. As part of its long-term strategy, the URA continues to encourage registration of taxpayers in the sector and filing of income taxes. However, given the highly profitable nature of some firms operating in the agriculture sector, they face few incentives to register and subject themselves to potential income tax enforcement action. Over the short term, it seems clear that the only way to tax income effectively in the agriculture sector is through some form of withholding tax.

\section{Use of withholding taxes in Uganda}

In interviews with URA officials, withholding taxes (WHTs) were most often advanced as the only feasible way to tax income in the agriculture sector. WHTs are used in many countries as a mode of collecting income taxes. The most common withholding mechanism involves some form of PAYE tax on income (Martin 2018). Employers are designated as tax agents, and withhold a proportion of employee salaries on behalf of the revenue authority. When employees file their income taxes, they can claim a credit for all WHTs paid throughout the year - and receive a refund if they have overpaid. Due to the general difficulty of enforcing income tax compliance in Uganda, the URA relies extensively on WHTs in many sectors, and in effect treats them as a separate category of tax.

In Uganda, a flat 6 per cent WHT rate is applied across a range of transactions, including management and professional fees, general supplies, and winnings from gaming and 
lotteries, as well as on employee salaries. Purchasers of these goods and services are designated as withholding agents, with the legal responsibility to remit 6 per cent of the total transaction value to the URA. These withholding taxes are typically passed on to suppliers in the form of lower prices for their goods or services. As a result of the liberal use of withholding taxes, they contributed roughly 37 per cent of total domestic tax collection, and 23 per cent of overall URA revenue collection, in 2019/20 (see Table 5). ${ }^{3}$

Table 5 Withholding taxes collected in Uganda by financial year

\begin{tabular}{llll}
\hline Financial year & Withholding tax (USh bn) & $\%$ of domestic tax collection & \% of overall collection \\
\hline $\mathbf{2 0 1 4} / \mathbf{1 5}$ & $2,160.10$ & $39 \%$ & $22 \%$ \\
\hline $\mathbf{2 0 1 5 / 1 6}$ & $2,502.87$ & $38 \%$ & $22 \%$ \\
\hline $\mathbf{2 0 1 6 / 1 7}$ & $2,792.93$ & $37 \%$ & $22 \%$ \\
\hline $\mathbf{2 0 1 7 / 1 8}$ & $3,150.40$ & $37 \%$ & $22 \%$ \\
\hline $\mathbf{2 0 1 8 / 1 9}$ & $3,657.96$ & $36 \%$ & $22 \%$ \\
\hline $\mathbf{2 0 1 9 / 2 0}$ & $3,912.82$ & $37 \%$ & $23 \%$ \\
\hline
\end{tabular}

The majority of WHT revenue comes from withholding on employee salaries, followed by withholding on the purchase of general supplies. When the amended 1 per cent withholding rate on agriculture products was enforced in 2018/19, it contributed about USh33 billion to public revenue, or about 1 per cent of total WHT collection.

Table 6 Withholding taxes collected in Uganda by transaction type (USh bn and \%)

\begin{tabular}{lllllll}
\hline Transaction type & $\mathbf{2 0 1 7 / 1 8}$ & $\mathbf{2 0 1 8 / 1 9}$ & $\mathbf{2 0 1 9 / 2 0}$ & $\mathbf{2 0 1 7 / 1 8}$ & $\mathbf{2 0 1 8 / 1 9}$ & $\mathbf{2 0 1 9 / 2 0}$ \\
\hline PAYE & $2,396.11$ & $2,811.30$ & $3,039.83$ & $\mathbf{7 6 \%}$ & $\mathbf{7 7 \%}$ & $\mathbf{7 8 \%}$ \\
\hline General supplies & 337.52 & 435.14 & 505.10 & $11 \%$ & $12 \%$ & $13 \%$ \\
\hline Foreign transactions & 152.99 & 102.94 & 114.49 & $5 \%$ & $3 \%$ & $3 \%$ \\
\hline Mgt. \& professional fees & 89.56 & 116.37 & 121.39 & $3 \%$ & $3 \%$ & $3 \%$ \\
\hline Dividends & 87.74 & 74.64 & 54.92 & $3 \%$ & $2 \%$ & $1 \%$ \\
\hline Government payments & 73.82 & 75.78 & 58.67 & $2 \%$ & $2 \%$ & $1 \%$ \\
\hline Winnings on gaming \& lotteries & 12.65 & 17.68 & 18.42 & $0 \%$ & $0 \%$ & $0 \%$ \\
\hline Agricultural supplies & & 32.5 & & & $1 \%$ & $100 \%$ \\
\hline Total withholding tax & $3,150.40$ & $3,666.35$ & $3,912.82$ & $100 \%$ & 100 & 100 \\
\hline
\end{tabular}

The URA thus has a well-developed withholding system used to collect income taxes from many sectors of the economy, which explains URA officials' enthusiasm for applying this mechanism to the agriculture sector. However, as discussed in the following sections, the application of WHT in the agriculture sector faces a steep political hill to climb.

\section{Strategies to collect revenue from the agriculture sector more fairly}

In general, there are four broad strategies that Uganda, and the URA in particular, could pursue to increase compliance among high income earners in the agriculture sector: (1) reinstating WHT on agricultural supplies, (2) upgrading the withholding tax system, (3)

3 Domestic tax collection includes revenue from personal and corporate income tax, VAT, domestic WHTs, rental tax, excise duties and gaming tax. Overall URA revenue collection includes all domestic taxes, as well as trade taxes, such as import duties, VAT on imports and export taxes, and non-tax revenue from various royalties and fees (URA 2011). 
expanding registration of large agricultural suppliers, and (4) increasing enforcement efforts on non-compliant large taxpayers in the sector.

\subsection{Reinstate WHT on agricultural supplies}

Because of the challenges in identifying taxpayers in the agriculture sector and encouraging income tax compliance, withholding taxes are one of the only ways to effectively tax agricultural income in Uganda. Uganda applies WHTs across many sectors of the economy, but they are not currently enforced for the supply of agricultural products.

Prior to 2018, there was a standard 6 per cent withholding rate applied to all sales of agricultural products in the country. However, this rate was widely seen as too high for farmers, and for political reasons the URA was unable to enforce it. In 2018, the Ministry of Finance proposed a reduction of the withholding rate on agricultural supplies to 1 per cent, on the grounds that it would be more affordable for farmers. Once Parliament amended section 118E of the Income Tax Act with the 1 per cent provision, the URA restarted enforcement actions in the sector. When designated agents purchased agricultural products from suppliers above the threshold amount of USh1 million, they were required to withhold 1 per cent of the sale value and remit it to the URA. Although there had previously been a 6 per cent WHT in place, the URA's enforcement of the new 1 per cent rate felt like a new tax for the many non-compliant suppliers in the sector. As a result, URA enforcement met increasingly stiff resistance from farmers, suppliers and politicians.

Despite growing resistance, the WHT amendment resulted in significant revenue collection from agricultural suppliers. By the end of FY2018/19, about USh33 billion had been collected - almost twice the amount of income tax collected from the agriculture sector in the same year. In 2018/19 only USh17.5 billion was collected in income taxes from the agriculture sector, and in 2017/18 only USh4 billion was collected. These statistics suggest that the most effective way to tax the agriculture sector (other than PAYE on employee earnings) is by withholding on the supply of agricultural products.

Shortly after its introduction, the new WHT rate became the focus of intense political debate. Ultimately, the amendment was repealed by Parliament, and agricultural products were added to the list of items exempt from the general 6 per cent WHT. Repeal of the WHT rate severely limited the tools available to the URA to increase revenue collection from the agriculture sector. One of the main contentions of the amendment's opponents was a gap in the designation of withholding agents. Only larger purchasing firms were designated by the URA as withholding agents, with smaller firms escaping this responsibility because of their size. The larger firms objected strongly to this gap in designation, as the smaller firms were engaged in the same economic activity. It was widely reported at the time that those who had been designated as withholding agents began losing business, as farmers stopped selling to them to avoid the WHT. As they lost business, some designated withholding agents stopped complying with their obligations. Responding to this resistance, in 2019 Parliament scrapped the 1 per cent withholding rate, and the sector is not currently subject to any WHT.

The 2020 Income Tax Amendment Bill included a proposal to re-introduce the WHT on agricultural products, but this time at the standard 6 per cent rate. Essentially, the URA was suggesting that there is no need to create a special treatment category for agricultural products. The proposal was rejected by the Finance Committee of Parliament on the grounds that similar challenges were likely to be faced as before. Farmers would prefer to sell to nondesignated withholding agents, or, if they were forced to sell to a withholding agent, would increase their prices to account for the 6 per cent levy. In its report, the Committee suggested that the proposal to reintroduce agricultural WHT be put on hold until a clear, equitable and practical mechanism is developed to directly tax small and medium enterprises in the agriculture sector (PoU 2020). 
Civil society organisations (CSOs) have played an important role in the national conversation around agriculture sector taxation. In general, they are supportive of WHTs on the supply of agricultural products - although they caution that enforcement action needs to target only the largest commercial suppliers. A 2015 policy paper submitted by an NGO consortium ${ }^{4}$ to the Ministry of Finance supported enforcement of the 6 per cent WHT on large commercial suppliers in the agriculture sector (CSBAG et al. 2015). During the controversy surrounding the 2018 WHT amendment, CSOs carried out public education campaigns supporting the enforcement of the new WHT rate on commercial farmers. Throughout the controversy, their general position was that the URA should avoid enforcing these measures on smallholder farmers. To inform the development of the 2021/2022 tax bill, a group of CSOs under the banner of Tax Justice Network Uganda (TJNU) submitted a series of alternative revenue proposals, including a suggestion to reintroduce WHT on agricultural supplies at a rate of 0.5 per cent. Taking into account the previous controversy and political resistance to WHTs in the agriculture sector, the group believes that a 0.5 per cent rate may be more acceptable, and enforceable by the URA. The group estimates that a 0.5 per cent rate could raise roughly USh25 billion annually - about 60 per cent more than all income tax collected from the sector in FY2019/20. In sum, CSOs have been broadly supportive of attempts to tax the agriculture sector through a withholding regime, although they stress that the URA should target enforcement actions specifically towards the larger commercial suppliers in the sector.

\subsection{Upgrade the withholding tax system}

There are a number of persistent weaknesses in the URA's overall withholding system that need to be addressed. The two main weaknesses are: (1) the TIN and name of suppliers from whom the tax is being withheld is not currently a mandatory field, and (2) the system does not validate the TIN of suppliers that are specified in the return. As a result, there are a large number of suppliers declared in the URA system that cannot be traced.

To address this weakness, URA could update its e-tax software to make supplier TIN a mandatory field for withholding agents. As supplier TIN is not currently a mandatory field, many withholding agents leave it blank, and, as a result, suppliers cannot be traced, even when they are recorded to have received large payments. If a supplier does not have a TIN, enough details need to be captured to allow them to be identified and traced.

The URA's e-tax software could also be upgraded to automatically validate the TINs of suppliers declared in WHT returns submitted by withholding agents. Validating TINs before a WHT return can be submitted would make it easier for URA to follow up with declared suppliers to ensure compliance with other tax liabilities, such as income tax. Additionally, making the TIN a mandatory validated field would force withholding agents to confirm the registration status of their suppliers, and thereby encourage voluntary registration in the taxpayer database. Both these solutions could in theory be implemented automatically in the URA's e-tax software, and should not add a significant administrative burden on the authority.

As a final method to upgrade the existing withholding system, the URA could ring-fence agricultural expenses included in corporate income tax returns, and require that firms fully declare the sources to which they made these payments. If agricultural expenses are ringfenced in corporate income tax returns, then URA could add an additional provision that these expenses are only deductible if supplier details, such as names and TINs, are provided and validated. Such a ring-fencing policy would provide an incentive for firms to accurately identify their agricultural suppliers on behalf of the URA.

The consortium included the Civil Society Budget Advocacy Group, SEATINI Uganda, ActionAid Uganda, Uganda Debt Network, Development Initiatives and the Water Governance Institute. 


\subsection{Target highly profitable agricultural suppliers for registration}

Those earning the highest profits from agriculture are often those further along the supply chain from direct production. For example, produce buyers - and especially those that subsequently add value to produce - that then fulfil supply contracts to large institutions such as government. URA could focus its income tax enforcement activities first on those firms fulfilling large supply contracts to government agencies.

Additionally, as noted by Kangave et al. (2016) in their paper on high net worth individuals (HNWIs) in Uganda, many wealthy individuals invest in large areas of agricultural land and livestock. Uganda is a 'real property' economy, in the sense that instead of depositing their money in bank accounts or investment instruments like equity and bond securities, wealthy individuals prefer to invest in physical structures, such as land and commercial property (Kangave et al. 2016). In the Ankole region, for instance, cattle serve as a 'living bank' - they are not held to meet household consumption needs, but rather as a store of wealth to be sold when families need to meet larger expenses, such as school fees or medical bills (Wurzinger et al. 2008). As a result, agricultural land represents an important method of amassing and preserving wealth for Uganda's HNWls (Kangave et al. 2016). Because of the various challenges outlined above, agricultural income generated by HNWIs frequently escapes taxation.

The compliance investigation cases outlined in the previous section indicate that there are a number of suppliers fulfilling valuable contracts to large corporate entities, but paying very little tax overall. In the short term, URA could therefore focus on expanding registration of the suppliers most likely to be earning high incomes in the sector, and identifying ownership by HNWIs, to ensure that all appropriate information is collected and enforcement activities are able to proceed effectively.

\subsection{Increase enforcement on non-compliant taxpayers}

As discussed above, tax compliance of agricultural suppliers in Uganda appears to be very low. Many are not paying any taxes at all, and those that are paying appear to be grossly under-declaring their taxable income. Interviews with URA officials revealed that many Ugandans do not know that income derived from agriculture is taxable through the same mechanisms as any other form of income. There is a widespread perception in Uganda that agricultural activities should, and do, exist outside the formal tax system. As a result, efforts to encourage voluntary compliance in the sector have proven to be unsuccessful.

Some data already exists within the URA to help target enforcement efforts on profitable, non-compliant taxpayers in the sector. Periodic investigations, such as those from the sugarcane and fishery industries outlined above, provide a starting point for identifying some high-earners in the sector. Due to limited data analysis capacity, however, these investigations and administrative data are rarely used for this purpose. URA could focus on strengthening its capacity for internal data analysis - perhaps through training or additional hiring - to perform more detailed risk analysis to inform enforcement efforts targetting highly profitable players in the agriculture sector. Pursuing this enforcement is likely to encounter resistance, and will need to be accompanied by consistent political will. 


\section{Making agricultural taxation a political reality}

Whatever strategies are pursued to tax the agriculture sector more fairly, the primary challenge is likely to be political in nature. As demonstrated by the stiff backlash to the 2018 Income Tax Amendment, objections are likely to follow two main threads. The first is that taxation of the agriculture sector harms smallholder farmers, and the second is that gaps in the designation of withholding agents causes some farmers to avoid selling to these agents, and creates unfair distortions in the sector.

The claim that agriculture taxation harms smallholder farmers can be countered by focusing initial enforcement efforts on the largest suppliers most likely to be earning high incomes. The URA already has administrative data available to begin targeting some of these, and could gain access to more information through coordination with other government agencies purchasing large supplies of agricultural products. The URA should thus avoid targeting smaller farmers, and focus on large suppliers that fulfil contracts to government institutions, such as the National Agricultural Advisory Services (NAADS) and Operation Wealth Creation (OWC), ${ }^{5}$ as well as large private institutions, such as schools and factories.

Countering objections to the designation of withholding agents in the agriculture sector may prove more challenging. One option would be to simply designate all purchasers in the sector as withholding agents. Some may face capacity constraints in fulfilling this obligation, but the URA could institute taxpayer education campaigns and outreach to facilitate their new role.

Additionally, the URA could consider advocating for a lower rate if WHT being applied to the sector, perhaps the 0.5 per cent rate proposed by the TJNU in 2020 . This lower rate would demonstrate that the URA is listening to the concerns of farmers and other stakeholders. It could be increased in subsequent legislation, once producers and withholding agents have become more accustomed to participating in the broader WHT system.

The success of more appropriate agriculture sector taxation will rely on strong political will, in particular from the President. As mentioned above, many of the largest commercial producers in the agriculture sector are themselves MPs or top government officials overcoming resistance on this front will thus require clear and consistent political will from the top executive. To convince the head of state, top politicians and public officials, the URA will need to be very clear from the start of negotiations that the purpose of enforcement is not to penalise small and subsistence farmers, or to undermine investment in the sector, but rather to target the intermediate traders and large producers of agricultural products. These firms and individuals are already legally liable to pay income taxes, but due to the structure of the sector it is very challenging for the URA to identify these taxpayers and enforce compliance.

CSOs can also be important allies in emphasising that the URA is only pursuing enforcement against the largest commercial suppliers, and that smallholder farmers will not be impacted by stronger enforcement measures. The URA already has sufficient information from previous investigations and existing administrative data to begin pursuing enforcement on the large suppliers - provided the political will to do so is forthcoming.

The recent experience of the coronavirus pandemic in Uganda may provide a novel opportunity to push forward efforts to tax high-income earners in the agriculture sector.

NAADS is a semi-autonomous agency within the Ministry of Agriculture, Animal Industry and Fisheries that delivers agricultural advisory services and facilitates agricultural value chain development. OWC is a government agency created in 2013 with the mandate to facilitate the transformation of subsistence farmers into commercial farmers. 
Uganda implemented a strict lockdown strategy in response to the coronavirus crisis, including nightly curfews and the suspension of business activities requiring travel and faceto-face contact. The sectors hit hardest by the lockdowns included tourism, aviation services, hotels and accommodation, recreation, education, transport, and wholesale and retail - in short, the sectors from which Uganda currently collects much of its tax revenue. As a result of the lockdown strategy, the URA recorded a historic revenue shortfall of USh2.5 billion between March and June 2020 - only $66.7 \%$ of the 2020 collection target (Stewart-Wilson and Waiswa 2020). For the same period in $2019,98.8 \%$ of the collection target was reached, and $100.1 \%$ in 2018 . Uganda's government already has significantly less fiscal firepower than Western countries to respond to crises like the coronavirus pandemic (Moore 2020); and additional resources are required to support the crisis response effort.

The agriculture sector is unlikely to be affected by crises like the coronavirus pandemic to the same extent as sectors that make up Uganda's contemporary tax base. As an essential service, the agriculture sector is not subject to public health lockdown measures. Demand for agriculture products is likely to remain relatively constant, regardless of this crisis. As a large contributor to economic activity in the country, the agriculture sector presents a sustainable and resilient source of potential public revenue. Strengthened tax enforcement in the agriculture sector can thus be framed as a strategy to mobilise the country's domestic resources against unexpected crises. Framing agricultural taxation as a matter of national security in this way may help with its political acceptance.

\section{Recommendations for the way forward}

Agriculture presents a unique opportunity to collect more revenue from a sector that has long been overlooked by domestic revenue mobilisation efforts. Additionally, resources raised from the agriculture sector could be used to support Uganda's response to crises - such as the coronavirus pandemic - by redistributing resources from sectors that have been largely unaffected to those sectors that have been most disrupted.

Agriculture in Uganda makes up nearly a quarter of total GDP, but contributes less than 1 per cent to total tax revenue. Much of this economic activity takes places at subsistence level, and should be exempt from taxation. However, the URA already has data indicating there are a number of agricultural suppliers earning high incomes in the sector that pay very little if any tax. These highly profitable agricultural players are protected by existing legislation, such as the absence of a withholding tax, and benefit from the URA's limited enforcement of existing tax obligations.

The following recommendations outline the steps the URA and the government of Uganda should take to increase revenue mobilisation from the agriculture sector, while avoiding adverse impacts on small and subsistence-level operations.

Reintroduce withholding tax on agricultural supplies above a certain threshold. Experience has demonstrated that, beyond PAYE on employee salaries, withholding taxes are the only way to effectively tax agricultural income in the short and medium term. The reintroduction of WHT on agricultural supplies can also be used as a tool to encourage potential taxpayers in the sector to register with URA, with the long-term goal of expanding the scope for direct taxation of agricultural producers. The URA should consider advocating for the reintroduction of a reduced WHT rate on the sector, perhaps at 0.5 per cent to make its reintroduction more politically feasible.

Upgrade the existing withholding system to make supplier TIN a mandatory field. Supplier TIN is not a mandatory field in WHT returns under the existing system, and it is not 
automatically validated by the URA's e-tax software. As a result, the URA cannot track agricultural suppliers effectively, even when large purchases are declared by some withholding agents. Making supplier TIN a mandatory and automatically-validated field would encourage registration by all agricultural suppliers, and help to facilitate tracking.

Consider ring-fencing agricultural expenses on corporate income tax returns, and only allow deductions if sufficient identifying information on suppliers is provided. This would essentially shift the identification burden from the URA onto firms. Large purchasers of agricultural products would have an incentive to ensure that their suppliers are appropriately registered with the URA. Recognising that many agricultural suppliers may not currently have TINs, the option should be available to provide sufficient identifying information instead so that suppliers can be identified and tracked by the URA.

Focus on identifying the most profitable suppliers in the agriculture sector - much of this information already exists from internal URA investigations. The URA already has a great deal of information on the largest agricultural suppliers and their tax compliance behaviour. This internal information suggests that these large suppliers are also earning high, untaxed income in the sector. Acting on this information requires a strengthened capacity for data analysis, as well as the political will to pursue expanded enforcement measures on these potential taxpayers.

Focus enforcement efforts first, and primarily, on large suppliers in the agriculture sector - and especially on those fulfilling large government and private sector contracts. An objection often raised by those opposed to agriculture sector taxation is that it will disproportionately harm small-scale and subsistence farmers. To counter this narrative, the URA should focus enforcement efforts primarily on the largest suppliers in the sector, and widely publicise the results of their investigations and enforcement actions. As a first step, the URA should gather information on those suppliers fulfilling large contracts to government and corporate entities.

Engage with CSOs to explain plans to increase revenue mobilisation from the agriculture sector, and pre-empt objections that the burden will fall primarily on smallholder farmers. CSOs have been broadly supportive of agriculture sector WHTs in the past, provided the burden does not fall on the majority of smallholder farmers. If the burden of WHT enforcement is targeted towards the biggest commercial farmers and dealers in agricultural produce, then CSOs are likely to be an important and influential ally in support of proposals to increase revenue generation from the sector. The URA should pro-actively engage with CSOs to reassure them that any new WHT measures applied will account for their concerns.

Lobby top government officials and the President on the need to tax the agriculture sector more appropriately, with an emphasis on its implications for national security. Given the strong political resistance to taxation of the agriculture sector among MPs and government officials, leadership to improve collection from the sector will need to come from the head of government. At the same time, the coronavirus pandemic has made it clear that the URA must diversify its revenue base to ensure sustainability and resilience in the face of unexpected crises. By emphasising the national security implications of strengthened agricultural taxation, and the intended focus on non-compliant large suppliers in the sector, the URA may be able to increase political acceptance of agricultural taxation.

Increase URA capacity to pursue enforcement actions against the largest players in the agriculture sector, based on existing data. The URA currently has limited data analysis capacity, despite the large volume of administrative data that is produced each year. The URA should consider hiring additional data analysts to facilitate the use of existing information in more risk-based audits. 


\section{References}

Ahmad, E. and Stern, N. (1989) 'Taxation for developing countries', in Handbook of Development Economics, Elsevier, https://econpapers.repec.org/bookchap/eeedevchp/2-20.htm

Ahmed, Q. and Mohammed, S. (2010) 'Determinant of Tax Buoyancy: Empirical Evidence from Developing Countries', European Journal of Social Sciences 13(3): 408-414

Bates, R. (1981) Markets and states in tropical Africa: The political basis of agricultural policies (updated and expanded, with a new preface), University of California Press

Bird, R. (1974) 'Agricultural taxation in developing countries', Finance and Development 11(3): 35-37

CSBAG, SEATINI, AAIU, UDN, DI, \& WGI (2015) Civil Society Position on Tax Revenue Measuresfor FY2015/16, Civil Society Budget Advocacy Group, SEATINI Uganda, ActionAid Uganda, Uganda Debt Network, Development Initiatives, and the Water Governance Institute, https://csbag.org/wp-content/uploads/2015/10/CIVIL-SOCIETYPOSITION-ON-TAX-REVENUE-MEASURES-FOR-FY-105-16-Press-Statement.pdf

de Jantscher, M. and Bird, R. (1992) 'The reform of tax administration', in M. de Jantscher and R. Bird (eds), Improving Tax Administration in Developing Countries, International Monetary Fund. https://www.elibrary.imf.org/view/IMF071/034629781557753175/03462-9781557753175/03462-9781557753175.xml?redirect=true

Devarajan, S., Go, D., Schiff, M. and Suthiwart-Narueput, S. (1996) The Whys and Why Nots of Export Taxation, Policy Research Working Paper No. 1684, The World Bank, https://doi.org/10.1596/1813-9450-1684

Goedde, L., Ooko-Ombaka, A. and Pais, G. (2019) Winning in Africa's agricultural market, McKinsey \& Company, https://www.mckinsey.com/industries/agriculture/ourinsights/winning-in-africas-agricultural-market

Hoff, K. (1991) 'Land Taxes, Output Taxes, and Sharecropping: Was Henry George Right?', The World Bank Economic Review 5(1): 93-111

Kangave, J., Nakato, S., Waiswa, R. and Zzimbe, P. (2016) Boosting Revenue Collection through Taxing High Net Worth Individuals: The Case of Uganda, ICTD Working Paper 45, Brighton: Institute of Development Studies, https://www.ictd.ac/publication/boosting-revenue-collection-through-taxing-high-networth-individuals-the-case-of-uganda/

Khan, M. (2001) 'Agricultural taxation in developing countries: A survey of issues and policy', Agricultural Economics 24: 315-328

Krueger, A. (1991) The political economy of agricultural pricing policy, published for the World Bank by Johns Hopkins University Press

Martin, I. (2018) 'Working-Class Power and the Taxation of Current Earnings: Danish PayAs-You-Earn Income Tax in Comparative Perspective', in G. Huerlimann, W. Brownlee and E. Ide (eds), Worlds of Taxation: The Political Economy of Taxing, Spending, and Redistribution Since 1945, Springer International Publishing, https://doi.org/10.1007/978-3-319-90263-0_4

Mayega, J., Ssuuna, R., Mubajje, M., Nalukwago, M. I. and Muwonge, L. (2019) How Clean is our Taxpayer Register? Data Management in the Uganda Revenue Authority, African Tax Administration Paper 12, Brighton: Institute of Development Studies

Moore, M. (2020) 'How can African tax collectors help cope with the economic impacts of Covid-19?', April 8, The International Centre for Tax and Development, https://www.ictd.ac/blog/africa-tax-cope-economic-impacts-covid-19-coronavirus/

Newbery, D. (1987) 'Agricultural Taxation: The Main Issues', in D. Newbery and N. Stern (eds), The Theory of Taxation for Developing Countries, published for the World Bank by Oxford University Press

OECD (2019) Taxation in Agriculture, OECD, https://doi.org/10.1787/073bdf99-en

Okuja, J. (2018) Domestic Tax Laws of Uganda, TASLAF Advocates and Consultants, http://ugandanlawyer.com/wp-content/uploads/2019/02/DT_Laws_2018_Edition.pdf 
PoU (2020) Report of the Committee on Finance, Planning and Economic Development of the Income Tax (Amendment) Bill, 2020, Parliament of Uganda, https://parliamentwatch.ug/wp-content/uploads/2020/04/FPED3-20-Report-on-theIncomeTax-Amendment-Bill-2020.pdf

Rajaraman, I. (2005) 'Taxing Agriculture in a Developing Country: A Possible Approach, in J. Alm, J. Martinez-Vazquez and S. Wallace (eds), Taxing the Hard-to-tax: Lessons from Theory and Practice, Emerald Group Publishing Limited, https://doi.org/10.1016/S0573-8555(04)68812-2

Sarris, A. (1994). Agricultural taxation under structural adjustment, Food and Agriculture Organization of the United Nations, http://www.fao.org/3/v3600e/V3600E00.htm\#Contents

Schiff, M. and Valdés, A. (1992) The plundering of agriculture in developing countries, World Bank

Skinner, J. (1993) 'If Agricultural Land Taxation Is so Efficient, Why Is It so Rarely Used?', in K. Hoff, A. Braverman and J. Stiglitz (eds), The economics of rural organization: Theory, practice, and policy, published for the World Bank by Oxford University Press, http://digitallibrary.un.org/record/138342

_ (1991) 'Prospects for Agricultural Land Taxation in Developing Countries', World Bank Economic Review 5(3): 493-511

Stewart-Wilson, G. and Waiswa, R. (2020) 'Uganda should tax "Covid-19 winners" to fill revenue gaps', June 15, International Centre for Tax and Development, https://www.ictd.ac/blog/uganda-ura-tax-covid19-winners-revenue/

Timmer, P., McMillan, M., Badiane, O., Rodrik, D., Binswanger-Mkhize, H. and Wouterse, F. (2012) Patterns of growth and structural transformation in Africa, Thematic Research Note No. 2, International Food Policy Research Institute

UBOS (2019) 2019 Statistical Abstract, Uganda Bureau of Statistics

URA (2019) Withholding Tax: A Simplified Guide, Uganda Revenue Authority, https://www.ura.go.ug/Resources/webuploads/GNRART/WITHHOLDING\%20TAX.pdf

— (2014) What is Value-Added Tax (VAT)?, Uganda Revenue Authority, https://www.ura.go.ug/Resources/webuploads/INLB/Value\%20Added\%20Tax.compre ssed.pdf

- (2011) Taxation handbook: A guide to taxation in Uganda, Fountain Publishers

Valdés, A. (1996) Surveillance of agricultural price and trade policy in Latin America during major policy reforms, World Bank

Wurzinger, M., Ndumu, D., Okeyo, A. and Sölkner, J. (2008) 'Lifestyle and herding practices of Bahima pastoralists in Uganda', African Journal of Agricultural Research 3(8): 542 548 